\title{
Penanaman modal asing dan demokrasi: analisis data panel Provinsi-Provinsi di Indonesia
}

\author{
Dolly Mantora Hazmi*; Fitri Ayu; Neng Kamarni \\ Prodi Magister Ilmu Ekonomi, Fakultas Ekonomi, Universitas Andalas, Padang \\ *E-mail korespondensi: dollyhzk@gmail.com
}

\begin{abstract}
Foreign investment is very important for developing countries in economic development because of the low domestic investment capacity. Democracy is considered as one of the aspects that has an impact on investment, although there is still debate as to whether the impact is positive, negative, or neutral. Many other factors influence the inflow of foreign investment into a country, including the size of the economy, the level of wages, domestic investment, and the quality of human resources. Using a panel data regression analysis of provinces in Indonesia with a random effect model, we try to look at the factors that influence foreign investment inflows to Indonesia. We find that the democracy index in Indonesia's provinces does not affect foreign investment inflows
\end{abstract}

Keywords: FDI, Democracy, Investment, Indonesian democracy index

\begin{abstract}
Abstrak
Investasi Asing sangat penting bagi negara-negara berkembang dalam pembangunan perekonomian karena kemampuan investasi dalam negeri yang masih rendah. Demokrasi dinilai sebagai salah satu aspek yang memberi dampak terhadap investasi meskipun masih ada perdebatan terkait apakah dampaknya positif, negatif atau netral. Ada banyak faktor-faktor lain yang mempengaruhi masuknya arus investasi asing ke suatu negara, diantaranya ukuran perekonomian, tingkat upah, investasi dalam negari dan kualitas sumber daya manusia. Menggunakan analisis regresi data panel provinsiprovinsi di Indonesia dengan random effect model, kami mencoba melihat factor-faktor yang mempengaruhi arus masuk investasi asing ke Indonesia. Kami menemukan bahwa indeks demokrasi di provinsi-provinsi di Indonesia tidak berpengaruh terhadap arus masuk invetasi asing.
\end{abstract}

Kata kunci: PMA, Demokrasi, Investasi, Indeks demokrasi Indonesia

\section{PENDAHULUAN}

Para pendiri bangsa Indonesia menjadikan demokrasi sebagai dasar pengelolaan negara. Gagasan mengenai Indonesia adalah negara yang demokratis tertuang dalam Pancasila khususnya sila ke-4 dan Undang-undang Dasar Tahun 1945 pasal 28 yang menyatakan bahwa adanya kebebasan berpendapat yang merupakan unsur hakiki dari demokrasi (Bolo, 2019). Amin Rais dalam Irawan (2006), mengartikan bahwa demokrasi sebagai dasar hidup bernegara membuka peluang bagi rakyat untuk menilai kebijaksanaan pemerintah karena kebijaksanaan itu yang nantinya akan menentukan kehidupan rakyat itu sendiri.

Pasca kemerdekaan Indonesia, ada dua hal yang mendasari perkembangan demokrasi di Indonesia yaitu Maklumat Wakil Presiden no. X tanggal 16 Oktober 1945 mengenai kekuasaan legislatif yang diberikan kepada KNIP dengan membentuk 
kelompok kerja dan Maklumat tanggal 3 November 1945 tentang pembentukan partaipartai. Irawan (2006), menyebutkan bahwa awal mulanya gagasan demokrasi pluralistik lahir setelah adanya Maklumat Pemerintah tanggal 14 November 1945.

Praktek pertama demokrasi sendiri dilakukan di Negara Indonesia melalui pemilihan umum untuk memilih anggota DPR pada tanggal 29 September 1955 dan pemilihan anggota konstituante tanggal 15 Desember 1955. Pada tanggal 5 Juli 1959 diterbitkannya dekrit presiden menjadi titik balik tidak demokratisnya Indonesia karena lahirnya "Demokrasi Terpimpin" (1959-1965). Setelah masa demokrasi terpimpin oleh Presiden Soekarno, muncul lagi istilah "Demokrasi Pancasila" pada masa pemerintahan Presiden Soeharto (1967-1998) yang diartikan sebagai demokrasi semu karena peran rakyat dalam politik didramatisir. Masa reformasi tahun 1998 menjadi harapan baru bangkitnya sistem demokrasi di Indonesia. Angin reformasi menghembuskan harapan baru dalam kebebasan pers, sistem multipartai dan keterbukaan informasi (Bolo, 2019). Menurut Yusril Ihza Mahendra dalam Irawan (2006), pelaksanaan demokrasi sekarang sudah berpijak pada UUD 1945 yang telah diamandemen dan sudah menunjukkan kemajuan. Hal ini terbukti dengan telah terakomodirnya sebagian besar aspirasi masyarakat tentang penyelenggaraan pemerintahan.

Kajian tentang hubungan demokrasi dan ekonomi telah sejak lama dibahas oleh para peneliti, meskipun terdapat perdebatan mengenai hubungan antara demokrasi dan ekonomi. Menurut Hadhek (2015), kebebasan sipil berdampak positif terhadap pertumbuhan ekonomi serta hak-hak politik yang lebih dihargai akan meningkatkan investasi. Rezim otoriter dalam jangka pendek akan menghambat investasi karena kekhawatiran investor pada program pemerintah dalam jangka panjang (Pastor \& Sung, 1995). Sementara itu Tavares \& Wacziarg (2001) menemukan bahwa demokrasi berdampak terhadap penurunan ketimpangan pendapatan tetapi berdampak negatif terhadap akumulasi modal fisik. Dari literatur yang kami temukan, dampak dari demokrasi terhadap perekonomian terjadi melalui saluran investasi. Stabilitas politik menjadi salah satu ukuran dari investor untuk memutuskan apakah mereka akan menanamkan modalnya atau tidak.

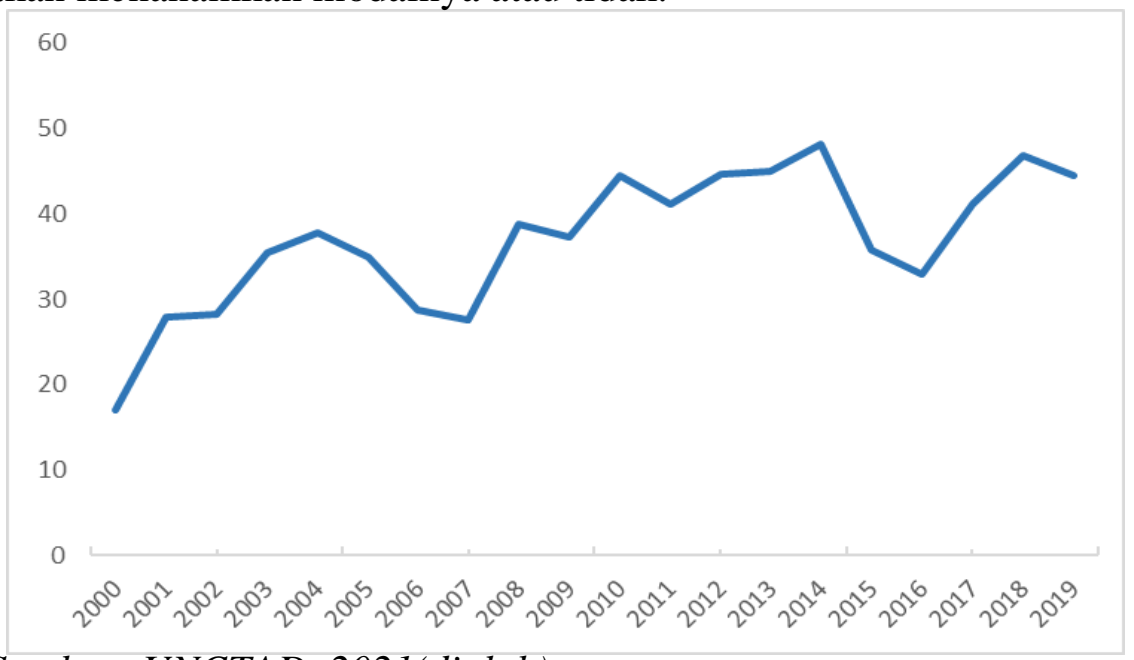

Sumber: UNCTAD, 2021(diolah)

Gambar 1. Persentase investasi asing di negara-negara berkembang terhadap total investasi asing, 2000-2019

Menurut Khachoo \& Khan (2012), salah satu masalah negara berkembang adalah kurangnya tabungan untuk membiayai investasi, sehingga membutuhkan investasi asing. Ada banyak literatur yang meninjau dampak dari Pananaman Modal Asing (PMA) terhadap perekonomian. Menurut Alfaro (2003), PMA berdampak 
positif terhadap sektor manufaktur, kemudian Oztruk dan Kalyoncu (2008) mendapati terdapat hubungan timbal balik antara PMA dan Produk Domestik Bruto. Sementara Iamsiraroj (2016), Borensztein et al. (1998), Seetanah dan Khadaroo (2007) menyatakan bahwa PMA berpengaruh positif terhadap Pertumbuhan. Zhang dan Daly (2011) meneliti terkait investasi yang dilakukan ke luar negari di China. Mereka menemukan investasi ke luar china ditentukan oleh ukuran perekonomian, kecepatan pertumbuhan ekonomi, keterbukaan perdagangan dan sumber daya. Peranan PMA dalam perekonomian menarik perhatian kami untuk menyelidiki faktor-faktor apa saja yang dapat mempengaruhinya. Beberapa literatur menyatakan bahwa faktor ekonomi sangat mempengaruhi PMA. Hal ini kami anggap wajar karena PMA adalah bagian dari perekonomian itu sendiri. Sementara itu faktor-faktor lain yang kami temukan dalam literatur yaitu infrastruktur (Khachoo \& Khan, 2012), teknologi (Sharma \& Bandara, 2010) , sumber daya manusia (Du et al., 2012) dan faktor stabilitas politik(Castro, 2014). Masih terbatasnya literatur tentang peranan faktor politik terhadap arus masuk PMA ke suatu negara menjadi alasan kami ingin memfokuskan penelitian ini pada dampak aspek politik terhadap arus PMA, khususnya tingkat demokrasi di Indonesia.

\section{LANDASAN TEORI}

\section{Pengaruh demokrasi terhadap PMA}

Menurut Kucera \& Principi (2014), demokrasi berdampak positif terhadap arus masuk modal asing terutama sektor jasa. Dalam penelitian mereka menggunakan tiga jenis proksi untuk mewakili demokrasi yaitu kebebasan sipil dan hak-hak politik yang dikeluarkan oleh Freedom House serta indeks polity IV. Sedangkan kami menggunakan Indeks Demokrasi Indonesia (IDI) yang dikeluarkan oleh BPS sebagai proksi dari variabel demokrasi. Indeks Demokrasi Indonesia adalah indikator komposit yang menggabungkan tiga aspek demokrasi yaitu Kebebasan Sipil (Civil Liberty), Hak-Hak Politik (Political Rights) dan Lembaga Demokrasi (Institution Rights). Tiga aspek tersebut diukur dari 28 indikator dengan menggabungkan pendekatan kuantitatif dan kualitatif. Untuk menggambarkan capaian tingkat demokrasi dalam IDI digunakan skala 0-100 dengan 0 adalah nilai terendah dan 100 adalah tingkat tertinggi (BPS, 2020).

\section{Pengaruh volume perekonomian terhadap PMA}

Variabel independen kedua yang kami gunakan yaitu volume perekonomian. Pasar yang lebih besar (ekonomi) akan menarik volume PMA yang lebih besar juga karena pengaruh skala ekonomi dalam konteks pencarian pasar investasi. Dalam beberapa kasus, faktor ini mungkin menjadi penentu utama PMA (Sharma dan Bandara, 2010). Kami menggunakan nilai logaritma natural Produk Domestik Regional Bruto (PDRB) sebagai proksi dari variabel ini merujuk yang digunakan oleh Tang (2011).

\section{Pengaruh investasi dalam negeri terhadap PMA}

Variabel independen ketiga adalah investasi swasta dalam negeri. Sangat terbatas literatur yang secara tegas menyatakan pengaruh dari Penanaman Modal Dalam Negeri (PMND) terhadap PMA. Ndikumana \& Verick (2008) meneliti hubungan timbal balik antara PMDN dan PMA. Mereka menemukan bahwa terdapat hubungan positif dua arah antara PMA dan PMDN.

\section{Pengaruh tingkat upah terhadap PMA}

Biaya tenaga kerja yang dianggap salah satu faktor utama yang berperan dalam keputusan suatu perusahaan asing untuk menanamkan modalnya. Tingkat upah yang rendah akan menurunkan biaya produksi sehingga keuntungan akan lebih besar. 
Khachoo dan Khan (2012) menemukan bahwa tingkat upah berpengaruh negatif dan signifikan terhadap arus masuk modal asing. Mereka menggunakan logaritma natural dari tingkat upah sebagai proksi biaya dari tenaga kerja.

\section{Pengaruh tingkat pendidikan terhadap PMA}

Variabel independen terakhir yang kami gunakan yaitu faktor modal manusia sebagai penentu arus masuknya modal asing. Arbatli (2011) dan Du et al. (2012) menggunakan pendidikan untuk mengukur kualitas modal manusia. Mereka memakai indikator berbeda untuk mewakili tingkat pendidikan. Arbatli (2011) menggunakan rata-rata lama sekolah sedangkan Du et al. (2012) menggunakan rasio jumlah siswa yang terdaftar di sekolah terhadap populasi. Meskipun demikian mereka mendapati hasil yang senada yaitu pendidikan berpengaruh positif terhadap aliran PMA.

\section{METODE}

Untuk melihat pengaruh demokrasi terhadap penanaman modal asing dalam tulisan ini akan menggunakan analisis regresi data panel pada provinsi-provinsi di Indonesia dalam periode 2015-2019. Variabel dependen yang kami digunakan adalah arus masuk modal asing sesuai dengan yang digunakan oleh Castro (2014), dengan mengubahnya menjadi bentuk logaritma natural untuk mengurangi kemiringan dalam distribusinya. Berdasarkan uraian dari pada landasa teori kami membentuk model faktor-faktor yang mempengaruhi arus masuk PMA seperti berikut:

$$
P M A_{i t}=\beta_{1} D_{e m_{i t}}+\beta_{2} P D R B_{i t}+\beta_{3} P M D N_{i t}+\beta_{4} U M P_{i t}+\beta_{5} R L S_{i t}+u_{i t}
$$

Dimana

$i \quad$ : Provinsi-provinsi di Indonesia

$t \quad$ : Waktu (2015-2019)

$u_{i t} \quad$ :error term

penjelasan terkait variabel-variabel tersebut dapat dilihat pada tabel 1 .

Tabel 1. Penjelasan variabel penelitian

\begin{tabular}{|c|c|c|c|}
\hline Variabel & Label & Definisi operasional & sumber data \\
\hline $\begin{array}{l}\text { Penanaman } \\
\text { modal asing }\end{array}$ & PMA & $\begin{array}{l}\text { Logaritma Natural dari arus masuk } \\
\text { penanaman modal Asing (juta dollar) }\end{array}$ & $\begin{array}{l}\text { Badan Koordinasi } \\
\text { Penanaman Modal }\end{array}$ \\
\hline Demokrasi & Dem & $\begin{array}{l}\text { Logaritma natural dari Indeks } \\
\text { Demokrasi Indonesia }\end{array}$ & Badan Pusat Statistik \\
\hline $\begin{array}{l}\text { Volume } \\
\text { prekonomian }\end{array}$ & PDRB & $\begin{array}{l}\text { Logaritma natural dari produk } \\
\text { domestik regional bruto (juta rupiah) }\end{array}$ & Badan Pusat Statistik \\
\hline $\begin{array}{l}\text { Penanaman } \\
\text { modal swasta } \\
\text { dalam negeri }\end{array}$ & PMDN & $\begin{array}{l}\text { Logaritman natural dari penanaman } \\
\text { modal swasta dalam negeri (milyar } \\
\text { rupiah) }\end{array}$ & $\begin{array}{l}\text { Badan Koordinasi } \\
\text { Penanaman Modal }\end{array}$ \\
\hline Tingkat upah & UMP & $\begin{array}{l}\text { Logaritma natural dari } \\
\text { Minimum Provinsi (Rupiah) }\end{array}$ & Badan Pusat Statistik \\
\hline Pendidikan & RLS & $\begin{array}{l}\text { Logaritma natural dari rata-rata lama } \\
\text { sekolah }\end{array}$ & Badan Pusat Statistik \\
\hline
\end{tabular}

Sumber: Data diolah, 2021 


\section{HASIL DAN PEMBAHASAN}

\section{Uji spesifikasi model}

Dalam regresi data panel perlu melakukan pemilihan model terlebih dahulu sebelum melakukan analisis terhadap hasil estimasi. Terdapat tiga model pada regresi data panel yaitu common effects model, fixed effect models dan random effect models. Untuk memilih model terbaik dilakukan menggunakan uji Chow, Uji Hausman dan uji Lagrange Multiplier.

Tabel 2. Hasi uji Chow

\begin{tabular}{clll}
\hline Effects Test & Statistic & d.f. & Prob. \\
\hline Cross-section F & 14.256913 & $(33,131)$ & 0.0000 \\
Cross-section Chi-square & 259.112785 & 33 & 0.0000 \\
\hline
\end{tabular}

Sumber: Data diolah, 2021

Uji Chow dilakukan untuk memilih model terbaik antara common effects atau fixed effects. Hasil dari tabel 2 menunjukkan nilai Prob lebih kecil dari nilai signifikansi sebesar lima persen yang artinya fixed effects lebih baik dibandingkan common effects.

Tabel 3. Hasi uji Hausman

\begin{tabular}{llll}
\hline Test Summary & Chi-Sq. Statistic & Chi-Sq. d.f. & Prob. \\
\hline Cross-section random & 7.990638 & 5 & 0.1568 \\
\hline \hline
\end{tabular}

Sumber: Data diolah, 2021

Uji Hausman dilakukan untuk memilih model terbaik antara fixed effects dan random effects. Berdasarkan Tabel 3 disimpulkan bahwa random effects lebih baik pada level signifikansi lima persen karena nilai prob lebih besar dari nilai signifikansi. Selanjutnya dilakukan uji Lagrange Multiplier untuk mengetahui apakah model common effects ataukah random effects yang lebih baik. Berdasarkan uji Lagrange Multiplier, model estimasi random effects merupakan model estimasi regresi data panel yang digunakan dalam penelitian ini pada tingkat signifikansi 5 persen.

Tabel 4. Hasi uji lagrange multiplier

\begin{tabular}{lccc}
\hline & \multicolumn{3}{c}{ Test hypothesis } \\
\cline { 2 - 4 } & Cross-section & Time & Both \\
\hline Breusch-Pagan & 160.2389 & 1.501146 & 161.7401 \\
Honda & $(0.0000)$ & $(0.2205)$ & $(0.0000)$ \\
& 12.65855 & -1.225212 & 8.084591 \\
King-Wu & $(0.0000)$ & -- & $(0.0000)$ \\
Standardized Honda & 12.65855 & -1.225212 & 3.005015 \\
& $(0.0000)$ & -- & $(0.0013)$ \\
Standardized King-Wu & 13.62856 & -1.002802 & 4.760716 \\
& $(0.0000)$ & -- & $(0.0000)$ \\
& 13.62856 & -1.002802 & 0.509403 \\
Sumber: Data diolah, 2021 & $(0.0000)$ & -- & $(0.3052)$ \\
\hline
\end{tabular}

Sumber: Data diolah, 2021

Karena model yang digunakan adalah random effects, sehingga tidak lagi memerlukan pengujian asumsi klasik. Menurut Gujarati dan Porter (2009), uji asumsi pada model random effects tidak diperlukan lagi, sebagaimana yang kita ketahui 
estimasi random adalah Generalized Least Square (GLS) yang melibatkan struktur varians covarians dalam proses estimasinya, sehingga sudah generalized.

Dari hasil estimasi dengan menggunakan random effect model yang dapat dilihat pada tabel 5 dapat disimpulkan bahwa secara keseluruhan model yang dibangun sudah sesuai (fit) dan valid. Hal ini ditandai dengan nilai Prob (F-statistic) sebesar 0,0000 pada level signifikansi 5 persen. Nilai R-Squared yang diperoleh yaitu 0,2196 yang artinya variabel indenpenden baru menjelaskan proporsi keragaman (varians) dari variabel dependen sebesar 21,96 persen.

\section{Uji signifikansi dan uji koefisien determinasi}

Dari hasil estimasi dengan menggunakan random effect model yang dapat dilihat pada tabel 5 dapat disimpulkan bahwa secara keseluruhan model yang dibangun sudah sesuai (fit) dan valid. Hal ini ditandai dengan nilai Prob (F-statistic) sebesar 0,0000 pada level signifikansi 5 persen. Nilai $R$-Squared yang diperoleh yaitu 0,2196 yang artinya variabel indenpenden baru menjelaskan proporsi keragaman (varians) dari variabel dependen sebesar 21,96 persen.

Tabel 5. Hasil estimasi model random effect

\begin{tabular}{cllll}
\hline \hline Variable & Coefficient & Std. Error & t-Statistic & Prob. \\
\hline \hline C & -0.685979 & 4.578541 & -0.149825 & 0.8811 \\
T_IDI & 0.223284 & 0.995106 & 0.224382 & 0.8227 \\
T_PDRB & 2.286951 & 0.363508 & 6.291330 & 0.0000 \\
T_PMDN & -0.115663 & 0.051536 & -2.244325 & 0.0261 \\
T_UMP & -1.783523 & 0.306598 & -5.817137 & 0.0000 \\
T_RLS & 2.057153 & 0.896194 & 2.295434 & 0.0230 \\
\hline R-squared & & \multicolumn{3}{c}{0.219617} \\
Prob(F-statistic) & & 0.000000 & \\
\hline \hline
\end{tabular}

Sumber: Data diolah, 2021

Berdasarakan p-value pada tabel 5 menunjukkan bahwa variabel demokrasi ternyata tidak berpengaruh signifikan secara statistik. Sehingga kami tidak dapat membuktikan bahwa demokrasi berdampak pada PMA. Temuan kami ini sejalan dengan hasil penelitian yang dilakukan oleh Castro (2014). Sementara itu ukuran perekonomian yang kami proksi melalui PDRB berkorelasi positif dan signifikan secara statistik pada tingkat $1 \%$. Hal ini menunjukkan bahwa semakin besar volume perekonomian akan meningkatkan aliran masuk PMA ke suatu wilayah. Peningkatan $1 \%$ PDRB akan meningkatkan 2,29 \% aliran masuk PMA. Dalam kasus provinsiprovinsi di Indonesia hal ini bukan hal yang baik karena akan meningkatkan disparitas antar provinsi.

Hampir seluruh literatur yang kami temukan menyatakan bahwa ukuran perekonomian berdampak positif terhadap arus PMA meskipun dengan proksi yang berbeda-beda. Tinjauan yang dilakukan oleh Tang (2011) serta Jurcau et al. (2011) menggunakan proksi yang sama dengan kami terkait volume perekonomian dan hasilnya sama dengan yang kami temukan.

Investasi swasta dalam negeri ternyata berdampak negatif dan signifikan terhadap arus PMA pada level 5 persen. Arus PMA yang masuk akan mengalami penurunan dengan meningkatnya nilai investasi dari dalam negeri yang dilakukan oleh pihak swasta. Kenaikan $1 \%$ PMDN akan menurunkan aliran masuk PMA sebesar $0,12 \%$. Dari gambar 2 terlihat arus PMA yang masuk cenderung mengalami penurunan sejak tahun 2017, sedangkan nilai PMDN pada tahun 2019 naik hampir dua kali lipat dibandingkan tahun 2015 . 


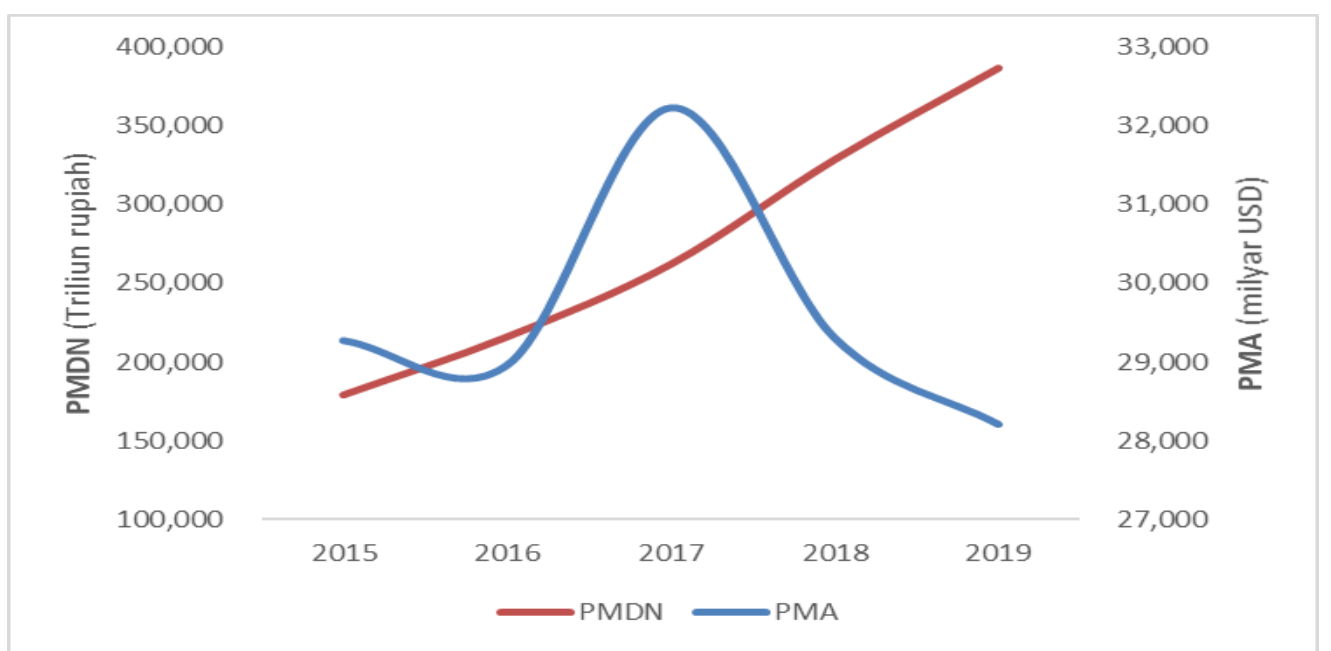

Sumber: Badan koordinasi penanaman modal (2021)

Gambar 2. Perkembangan nilai PMA dan PMDN, 2015-2019

Temuan kami ini berbeda dengan hasil penelitian yang dilakukan oleh Ndikumana dan Verick (2008). Hasil temuan mereka menyetakan bahwa ada hubungan timbal balik antara PMA dan PMDN dimana pengaruh antara keduanya adalah positif. Terbatasnya literatur yang meneliti pengaruh PMDN terhadap PMA menyulitkan kami untuk melakukan eksplorasi lebih dalam terhadap hasil ini.

Seperti yang kami harapkan, tingkat upah yang di proksi melalui upah minimum provinsi secara statistik berkorelasi negatif dan signifikan pada level 1\%. Artinya perusahaan asing lebih memilih melakukan investasi di provinsi dengan UMP lebih yang rendah dibandingkan provinsi dengan UMP yang lebih tinggi. Berdasarkan hasil estimasi yang kami lakukan dengan model random effects, UMP adalah faktor yang paling berpengaruh terhadap penurunan PMA di Indonesia dalam rentang 2015 hingga 2019. Rata-rata UMP di provinsi-provinsi di Indonesia pada tahun 2019 meningkat sebesar 44 persen dibandingkan tahun 2019. Sedangkan arus masuk PMA tidak mengalami peningkatan yang berarti sejak tahun 2015 hingga tahun 2019.

Kualitas sumber daya manusia dari segi Pendidikan yang kami proksi dengan rata-rata lama sekolah berpengaruh positif dan signifikan pada level 5\% terhadap aliran PMA. Kenaikan $1 \%$ rata-rata lama sekolah akan meningkatkan aliran PMA sebesar $2,06 \%$. Nilai rata-rata lama sekolah yang lebih tinggi menandakan kualitas manusia yang lebih terpelajar serta secara kuantitas memiliki tenaga kerja terdidik yang lebih banyak.

\section{KESIMPULAN DAN SARAN}

\section{Kesimpulan}

Penelitian ini mencoba melihat faktor-faktor apa yang mempengaruhi investasi asing di provinsi-provinsi di Indonesia. Hasil yang didapatkan adalah kami tidak dapat menyimpulkan bahwa demokrasi tidak mempengaruhi arus masuk PMA di provinsiprovinsi di Indonesia. Peningkatan PMA dipengaruhi oleh volume perekonomian, dan kualitas sumber daya manusia dari segi Pendidikan. Pengaruh volume perekonomian terhadap arus masuk PMA di provinsi-provinsi di Indonesia bisa berdampak terhadap peningkatan disparitas antar provinsi. Diperlukan kebijakan pemerataan oleh pemerintah pusat agar hal ini tidak terjadi di Indonesia, mengingat keputusan pemberian izin PMA ada di tangan pemerintah pusat.

\section{Saran}

Faktor yang berdampak negatif terhadap arus masuk PMA dalam penelitian kami ini adalah Investasi dalam negeri dan tingkat upah. Tingkat upah memberikan dampak 
paling besar terhadap penurunan arus masuk PMA. Hal ini tentu seharusnya menjadi perhatian khusus untuk pemerintah Provinsi di Indonesia sebagai acuan dalam penetapan UMP, terutama bagi provinsi yang volume perekonomian yang lebih kecil dibandingkan provinsi lainnya. Perlu kajian yang lebih cermat dan komperhensif agar nantinya nilai UMP yang ditetapkan tidak menjadi penghalang masuknya investasi asing. Karena investasi asing akan sangat membantu perkembangan perekonomian saat kemampuan investasi dari dalam negeri masih rendah.

\section{DAFTAR PUSTAKA}

Alfaro, L. (2003). Alfaro, L. (2003) Foreign direct investment and growth: does the sector matter? Harvard Business School, Business School in Boston: Massachusetts

Arbatli, E. (2011). Economic policies and FDI inflows to emerging market economies; IMF working paper, international monetary fund, Hal.1-25

Bolo, A. D. (2019). Demokrasi di Indonesia: pancasila sebagai kontekstualisasi demokrasi. Melintas, 34(2), 145-167. https://doi.org/10.26593/mel.v34i2. 3389.145-167

Borensztein, E., Gregorio, J. De, \& Lee, J.-W. (1998). How does foreign direct investment affect economic growth in China? Journal of International Economics, 45, 115-135. https://doi.org/10.1111/1468-0351.00095

BPS. (2020). Berita resmi statistik indeks demokrasi Indonesia. Diakses dalam http://bps.go.id, Tanggal 12 Juli 2020, Pukul 12.30 WIB

Castro, D. (2014). Foreign direct investment and democracy. Faculty Sponsor: Aziz Berdiev

Damodar N., Gujarati dan Dawn C. Porter. (2009). Basic econometric 5th Edition. McGraw -Hill: New York.

Iamsiraroj, S. (2016). The foreign direct investment-economic growth nexus. International Review of Economics and Finance, 42(March 2016), 116-133. https://doi.org/10.1016/j.iref.2015.10.044

Irawan, B. B. (2006). Perkembangan demokrasi di Indonesia. Perspektif, 5(3), 54-64. http://jurnal.untagsmg.ac.id/index.php/hdm/article/viewFile/312/364

Khachoo, A. Q., \& Khan, M. I. (2012). Determinants of FDI inflows to developing countries : a panel data analysis, Munich Personal RePEc Archive (MPRA), Department of economics, Pondicherry university, Centre for Development Studies, Trivandrum: Kerala

Ndikumana, L., \& Verick, S. (2008). The linkages between fdi and domestic investment: unravelling the developmental impact of foreign investment in Sub-Saharan Africa. 26(6), 713-726.

Oztruk, I., \& Kalyoncu, H. (2008). Foreign direct investment and growth: an empiricial investigation based on cross-country comparison. Munich Personal RePEc Archive(MPRA) Paper, 9636. 75-81

Sharma, K., \& Bandara, Y. (2010). Trends, patterns and determinants of Australian foreign direct investment. Journal of Economic Issues, 44(3), 661-676. https://doi.org/10.2753/JEI0021-3624440305

Tavares, J., \& Wacziarg, R. (2001). How democracy affects growth. European Economic Review, 45(8), 1341-1378. https://doi.org/10.1016/S00142921(00)00093-3

Zhang, X., \& Daly, K. (2011). The determinants of China's outward foreign direct investment. Emerging Markets Review, 12(4), 389-398. https://doi.org/10.1016 /j.ememar.2011.06.001 